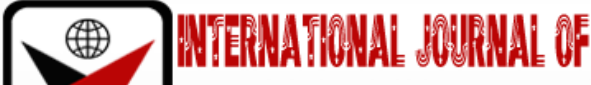

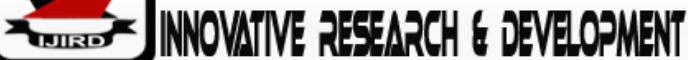

ISSN 2278-0211 (Online)

\section{Financing the Small and Medium Enterprises in Post COVID- 19 Nigerian Economies: Issues and Perspectives}

\author{
Nwulu Stephen Onyemere \\ Doctoral Student, Department of Finance and Banking, \\ University of Port Harcourt, River State, Nigeria
}

\begin{abstract}
:
The purpose of this paper is to explore the financing needs of Small and Medium Enterprises in the Post COVID-19 Nigeria Economy. The present state of the Economy was reviewed to determine how the pandemic has affected both the economy and the SMEs.Also a study to determine financing gaps of the SMEs in Nigeria using the simple descriptive means and standard deviations was carried out. The study is based on a sample of 150 small business owners across different sectors (Trade, Services, ICT, Education, and Hospitability) in Port Harcourt Rivers State. The results show that SMEs have financing gaps that are demand related. Consistent with previous studies, the results show that risk aversion, desire to maintain control and reputational effects are key factors explaining the demandside financing gaps of SMEs in Nigeria. An outlook of the post COVID-19 era projects a weak economy that would struggle to recover. This paper concludes that SMEs that are already faced with demand related financing gaps and aggravated by low sales and supply chain shocks caused by the pandemic should be more strategic in pursuing their financing needs in the wake of post COVID-19 dwindling economy. To strengthen and enhance the capabilities of SMEs, recommendations are made to both the SMEs and the Monetary Authorities.
\end{abstract}

Keywords: Financing gap, demand-side factors, SMEs, COVID -19

\section{Introduction}

With the recent outbreak of COVID 19 pandemic which has continued to exert negative impact on the world economy, it has become imperative to examine how the financing gap faced by small and medium scale enterprises (SMEs) has widened in Nigeria. According to Abraham and Schmukler (2017), low use of financial services by SMEs can be linked to both supply-side and demand-side factors. While a supply-side gap can be linked to the inability of the financial institutions to provide affordable credit needed to finance profitable investments, a demand-side problem occurs when there is limited opportunity to access and use financial services, which is caused by asymmetric information problem and which makes it difficult for financial institutions to ascertain the credit worthiness of small businesses.

According to Ozili (2020) the effect of COVID 19 on the global economy manifests in two ways. The first is the social distancing as a result of the spread of the virus led to the shutdown of financial markets, businesses and social events. Second is the flight to safety of consumption and investment among consumers and investors (Ozili\&Arun, 2020). The global stock market went down by about US $\$ 6$ trillion in wealth in one week from $24^{\text {th }}$ to $28^{\text {th }}$ February 2020 . The S\&P 500 index also lost over $\$ 5$ trillion in value in the same week in the US while the S\&P 500's largest companies experienced a combined loss of over $\$ 1.4$ trillion due to uncertainty and fear amongst investors about how the pandemic was going to affect the world economy (Ozili\&Arun, 2020). This led to massive loss of businesses. Developed countries like United States and UK offered fiscal stimulus packages in response. The International Monetary Fund (IMF) expects the global economy to contract by 4.4 percent in 2020, but to gradually recover and grow by $5.2 \%$ in 2021 . Growth in Emerging Market and developing Economies (EMDEs) has been projected to contract by $3.3 \%$ in 2020 , but rebound to $6.0 \%$ in 2021 . The Sub-Saharan Africa is also projected to contract by $-3.0 \%$ in 2020 and recover to 3.1\% in 2021.South Africa would decline by-8.0\% in 2020 and recover steeply to 3\% in 2021. Egypt is projected to be stable by growing by $3.5 \%$ in 2020 and also $2.8 \%$ in 2021 .

In Nigeria, the negative economic impact of COVID 19 is also substantial. Data from both Nigeria Bureau of Statistics (NBS) and Central Bank of Nigeria, as shown in Figure 1, reveal that the real GDP growth dropped considerably from approximately $2.1 \%$ in the first and second quarters of 2019 to $-6.1 \%$ in the second quarter of 2020 , hence putting an end to the trend of positive but low growth rates recorded since the second quarter of 2017 immediately after the economic recession. Also, according to NBS (2020), this declining trend in real GDP growth is a direct fallout of the countrywide shutdown that was aimed at fighting the COVID 19 pandemic (CBN, 2020). The country also recorded a significant revenue decline in the first and second quarters of 2020, with growth rate in government revenue being $-15.3 \%$ and $-22.4 \%$ respectively. This development has been linked to both COVID 19 pandemic and oil price shocks. Further, the period also witnessed a significant increase in money supply; while other macroeconomic variables such as public debt, 
inflation and exchange rate all reached their crisis levels (see Table 1 for the performance of selected macroeconomic variables).

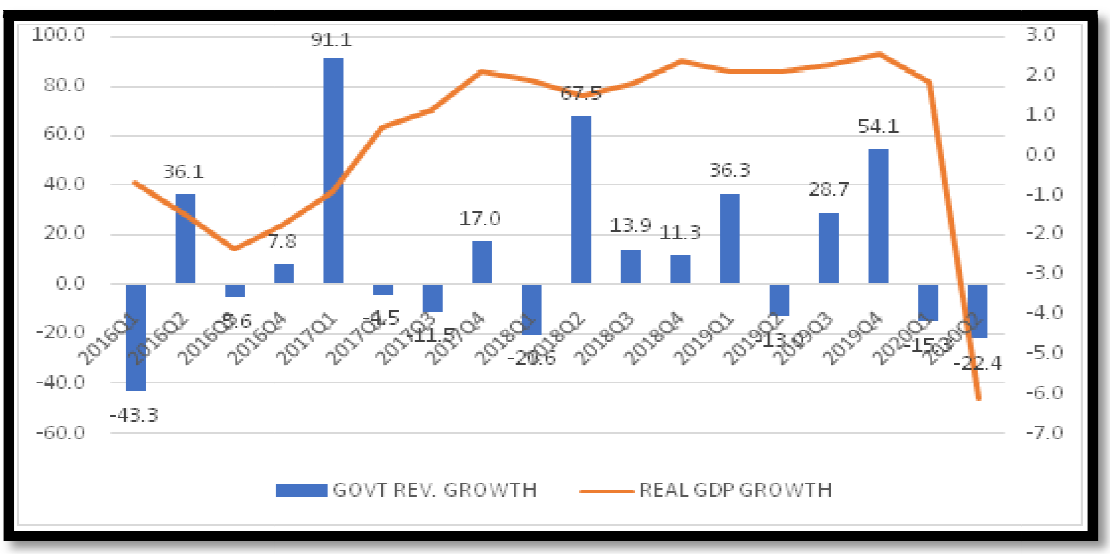

Figure 1: Government Revenue and Real GDP (\% YOY Change) Source: Data from NBS and CBN Quarterly Statistical Bulletin

\begin{tabular}{|c|c|c|c|c|c|c|c|c|c|}
\hline Date & $\begin{array}{c}\text { Real } \\
\text { GDP } \\
\text { Growth }\end{array}$ & $\begin{array}{c}\text { FGN } \\
\text { Revenue } \\
\text { Growth }\end{array}$ & DEBT/GDP & CPS/GDP & MS/GDP & Inflation & $\begin{array}{c}\text { Oil } \\
\text { Price }\end{array}$ & $\begin{array}{c}\text { Prime } \\
\text { Lending } \\
\text { Rate }\end{array}$ & $\begin{array}{c}\text { Exchange } \\
\text { Rate } \\
\text { (BDC) }\end{array}$ \\
\hline 2016Q1 & -0.7 & -43.3 & 62.2 & 84.9 & 100.8 & 12.8 & 37.8 & 16.8 & 322.0 \\
\hline $2016 Q 2$ & -1.5 & 36.1 & 69.2 & 91.1 & 102.0 & 16.5 & 48.5 & 16.8 & 348.0 \\
\hline $2016 Q 3$ & -2.3 & -5.6 & 63.6 & 85.7 & 98.0 & 17.9 & 47.4 & 17.1 & 464.0 \\
\hline $2016 Q 4$ & -1.7 & 7.8 & 59.5 & 75.4 & 97.7 & 18.5 & 53.5 & 17.1 & 490.0 \\
\hline $2017 Q 1$ & -0.9 & 91.1 & 73.6 & 86.0 & 107.5 & 17.3 & 52.1 & 17.4 & 385.0 \\
\hline $2017 Q 2$ & 0.7 & -4.5 & 72.6 & 81.3 & 104.8 & 16.1 & 47.4 & 17.6 & 366.0 \\
\hline $2017 Q 3$ & 1.2 & -11.5 & 69.4 & 75.0 & 101.6 & 16.0 & 56.8 & 17.9 & 364.5 \\
\hline $2017 Q 4$ & 2.1 & 17.0 & 69.5 & 71.3 & 91.7 & 15.4 & 65.1 & 17.7 & 363.0 \\
\hline $2018 Q 1$ & 1.9 & -20.6 & 79.8 & 78.6 & 102.4 & 13.3 & 66.9 & 17.4 & 362.0 \\
\hline $2018 Q 2$ & 1.5 & 67.5 & 72.9 & 72.6 & 95.6 & 11.2 & 75.4 & 16.8 & 360.5 \\
\hline $2018 Q 3$ & 1.8 & 13.9 & 67.2 & 68.8 & 92.5 & 11.3 & 79.6 & 16.6 & 360.0 \\
\hline $2018 Q 4$ & 2.4 & 11.3 & 69.2 & 64.5 & 94.7 & 11.4 & 62.0 & 30.8 & 361.0 \\
\hline $2019 Q 1$ & 2.1 & 36.3 & 78.4 & 75.4 & 106.3 & 11.3 & 67.7 & 14.9 & 359.0 \\
\hline $2019 Q 2$ & 2.1 & -13.0 & 73.4 & 70.7 & 99.7 & 11.2 & 66.7 & 15.8 & 360.0 \\
\hline $2019 Q 3$ & 2.3 & 28.7 & 69.3 & 67.4 & 92.7 & 11.2 & 65.3 & 15.2 & 359.0 \\
\hline $2019 Q 4$ & 2.6 & 54.1 & 69.2 & 67.4 & 87.9 & 12.0 & 68.6 & 15.0 & 362.0 \\
\hline $2020 Q 1$ & 1.9 & -15.3 & 80.3 & 79.4 & 100.1 & 12.3 & 32.3 & 14.7 & 409.0 \\
\hline $2020 Q 2$ & -6.1 & -22.4 & 91.1 & 86.5 & 104.7 & 12.6 & 40.3 & 15.7 & 455.0 \\
\hline
\end{tabular}

Table 1: Selected Macroeconomic Indicators

Source: Quarterly CBN Statistical Bulletin

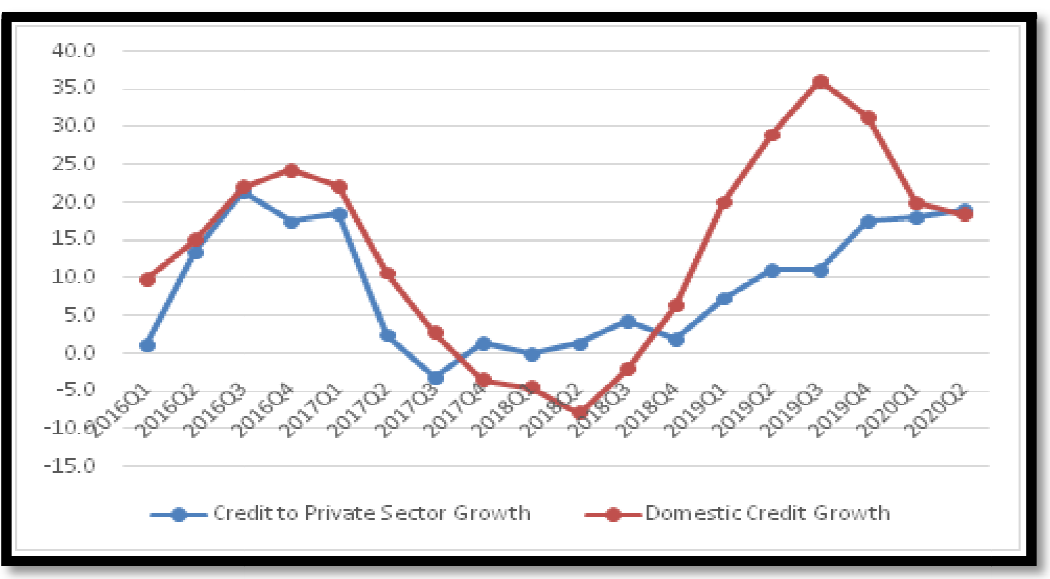

Figure 2: Domestic Credit and Credit to Private Sector (\% YOY Change) Source: Data from CBN Quarterly Statistical Bulletin 


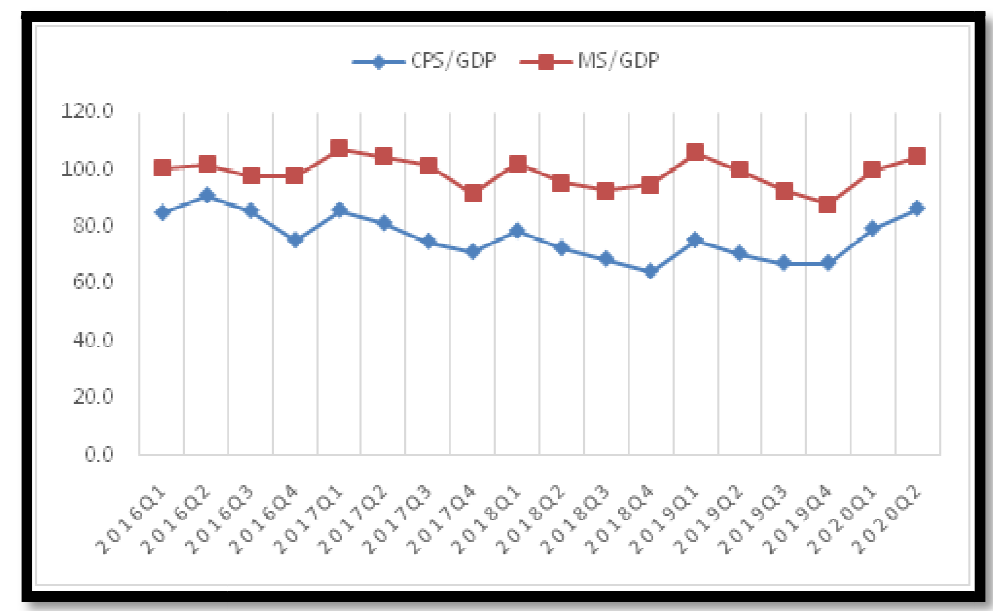

Figure 3: Credit to Private Sector and Money Supply (As a Percent of GDP) Source: Data from CBN Quarterly Statistical Bulletin

However, despite this ugly development in the macroeconomic and policy environment, the banking sector has continued to extend more credit to the private sector. As Figure 2 shows, although, domestic credit maintained a decreasing growth trend since the third quarter of 2018, the growth in credit to private sector has continued its upward trend since the third quarter 2017, reaching an all-time high of $18.9 \%$ in June 2020. The positive outlook in the credit to private sector growth can be explained by the Federal Government's effort in improving access to financial services and products through financial deepening even in the face of COVID 19 pandemic. This is also reflected in the recorded increase in both credit to private sector ratio to GDP and broad money ratio to GDP (see Figure 3), which respectively stood at $86.5 \%$ and $104.7 \%$ in June 2020 , compared with $70.7 \%$ and $99.7 \%$ in the corresponding quarter in 2019 .

The implication is that more credit is expected to be allocated to small and medium scale enterprises (SMEs). However, this appears not to be the case as the credit conditions survey report of the CBN indicated a decrease in the proportion of approved loan application for households in the second quarter 2020, which is attributed to the resolve by lenders to tighten the criterion used in credit scoring. This is corroborated by the earlier argument by Abraham and Schmukler (2017) that SMEs typically experience more difficulty in accessing finance from banks than large firms due to lack of publicly available information required for banks to objectively evaluate their credit worthiness. This, therefore, shows that the financing gap SMEs are currently experiencing in Nigeria is a demand-side problem; hence, providing demand-side evidence on the extent of this gap would shed more lights towards achieving the objective of economic recovery in the midst of COVID 19 by the Federal Government.

This, therefore, shows that the financing gap SMEs are currently experiencing in Nigeria is a demand-side problem, which urgently needs to be filled if the current government objective of rebounding the economy must see the light of the day.

There is no consensus as to the right definition of a small and medium enterprise. Definitions depend on the level of development in a given country. In countries such as United States of America, Britain and Canada definitions are in terms of annual income and employment level by the business (Ekpeyong and Nyong, 1992). In Nigeria, the National Policy on Micro, Small and Medium Enterprises (2007), published by Small and Medium Enterprises Development Agency of Nigeria (SMEDAN) considered its classifications and definition of SMEs from the point of view of National policy and posited that MSME's may be classified by size, sector, organisation, technology and location. Following this and other contributions by many organisations and stakeholders in the industry, it can be conclusively stated that a small size industry is classified and defined as one investing not less than N5 million but not more than N50 Million in assets excluding land and buildings and employing between 10-49 persons while medium sized industry can be defined as one investing not less than N50 million naira but not more than N500 million in assets excluding land and buildings and employing between 50-199 persons.

\subsection{Monetary Policy Initiatives of the Central Bank of Nigeria} pandemic:

According to the Central Bank of Nigeria, it came up with following palliatives to cushion the effect of the

- Extension of moratorium of one year on all principal repayments of CBN Intervention loans effective March 1, 2020.

- Reduction of all CBN Intervention facilities interest rates from 9\% p.a to 5\%p.a. for 1year effective March 1, 2020.

- Establishment of a N50Billion Importer credit facility through NIRSAL Microfinance Bank for households and Small and Medium sized Enterprises (SMEs)

- Credit support for the Health care Industry - Pharmaceutical companies intending to expand/open their drug manufacturing plants in Nigeria as well as to hospitals and health care practitioners.

- Regulatory forbearance - Grants all Deposit Money Banks leave to consider temporary and time-limited restructuring of the tenor and loan terms for businesses and households most affected by the outbreak of Covid 19 , particularly oil and gas, agriculture and manufacturing. 
- Strengthening of the CBN Loan Deposit Ratio Policy: Central bank further supports industry funding levels to maintain DMB's capacity to direct credit to individuals, households and businesses. This has resulted in a significant growth of credit to various sectors from N15.57 trillion to N19.33 trillion between end-May 2019 and end August 2020, an increase of N3.77 trillion.

CBN agrees to readily provide liquidity backstops as and when required in view of its role as banker to the Federal Government and lender of last resort.

A further study providing the demand side evidence of the financing gap of the SMEs using simple descriptive statistics has been carried out. The study focuses on SMEs operating in the different sectors (Trade, Services, ICT, Education, and Hospitability) in Port-Harcourt metropolis in Rivers State.

The remainder of this paper is organized in four sections. The next section is literature review, which is followed by methodology, and then data analysis. Section 5 contains summary, conclusion and recommendations.

\section{Literature Review on the Effect of COVID 19 on SMEs}

According to Abraham and Schmukler (2017), low use of financial services by SMEs can be linked to both supplyside and demand-side factors. While a supply-side gap can be linked to the inability of the financial institutions to provide affordable credit needed to finance profitable investment, a demand-side problem occurs when the limited opportunity to access and use financial services is caused by asymmetric information problem which makes it difficult for financial institutions to ascertain the credit worthiness of small businesses.

Wijaya (2020) used the qualitative research approach to examine the impact of Covid-19 on Micro, Small and Medium Enterprises (MSME) in East Java Province, Indonesia. The study employed the macroeconomic and/or microeconomic aspects, psychological aspects in the economy, and infectious disease disasters, which are proxy to health disasters due to the spread of epidemics/pandemics globally and the impact of the spread of Covid-19 in Indonesia. The study found that Covid-19 has a significant impact on the economy through sharp drop in sales revenue.

Using a survey approach Bartik, Bertrand, Cullen, Glaeser, Luca and Stanton (2020) investigated the impact of Covid-19 on the US small business. The study utilized more than 5,800 retail small businesses. The result shows that US small business are greatly affected financially by Covid-19 pandemic and also revealed many other small businesses that are going to be affected by the Covid-19 pandemic. The study also indicated the significant effect of well-designed and sustained economic and public health policy measures.

Nguyen, Ngo, Pham, Le (2020) in a random quantitative survey method examine the effect of policy related factors affecting the survival and development for 512 SMEs in ThanhHoa province in the context of COVID-19 -19 pandemic. More specifically, the study shows that the tax supporting policy and the preferential policies of the bank were important and significant factors positively affecting the development of enterprises during Covid-19 pandemic. The study also considered insurance policy, capital support packages of Government, the act of public administration and the role of professional association as important variables affecting the enterprise's development.

Adopting a bibliometric analysis approach Verma and Gustafsson (2020) investigated the Covid-19 research trends in the field of business and management utilizing 107 published articles indexed in Scopus and the web of Science. The analysis of the published literature identified 4 main research themes, which include, overall impact of covid-19 on business, covid-19 and technology, covid-19 and supply chain management, and covid-19 and service industry and 18 subthemes, which include covid-19 and business, value chain, trade, employment, risk communication, big data and advanced analytics, data driven decision making, emerging technologies, digital healthcare, infodemic, socio-technical transitions, inventory management, supply chain management, supply chain resilience, travel and tourism, education, and essential services. The study shows potential Covid-19 knowledge domains in the field of business and management. Lastly, coword analysis based on keywords provided insights into the main research themes/sub-areas related to the impact of Covid-19. It also reveals that Covid-19 pandemic will have short-, medium-, and long-term effects on various aspects of society and businesses.

Hadi and Supardi (2020) in a study to explore the revitalization strategy for small and medium enterprise after Covid-19 pandemic for Yogyakarta conducted a descriptive analysis using both primary and secondary data. The study shows that in relation to challenges faced by SMEs during the Covid-19 pandemic, they will experience a slowdown after the Covid-19 pandemic; hence revitalization strategy using Business Model Canvas (BMC) is one of the practical and appropriate alternatives.

Using descriptive research design Lemi, Bogale and Mengesha (2020) examined the influence of Covid-19 on Micro Small and Medium Enterprise MSME operating in Ethiopia. The study shows that Covid-19 pandemic has negative consequences on MSMEs as raw material supply was stopped, shortage of workers happened; shortage of working capital created, their operational cost increased, and decline in consumers consumption.

Alonso, Kok, Bressan, O'Shea, Sakellarios, Koresis, Solis and Santoni (2020) in an exploratory study of 45 predominantly small hospitality firms underscores the key concerns, ways of coping, and the changes and adjustments undertaken by these firms' owners and managers during the COVID-19 outbreak. The results suggest three second-order themes representing 'business', 'the unknown', and 'human dimensions', all of which derive from the emerging first-order codes, or from multiple comments. These dimensions contribute to understanding the discourses underpinning relationships between business and against the backdrop of an extreme context where a myriad of concerns can systematically engulf business owners and managers. Also, from study, financial impacts emerged among participants' responses, distantly followed by the climate of uncertainty. The study illustrates processes manifested through activities and adaptive capacities that allowed participants and their firms to embark on a positive trajectory to function and therefore adapt after this devastating event. Thus, together, these frameworks enable insight into the adaptability and 
coping ability within the entrepreneurial mindset in the aftermath of such devastating circumstances as Covid-19. Holistically, the frameworks also further reveal the entrepreneurial psyche and resilience in what will be noted as one of the most challenging times in modern history.

Sharma, Adhikaryb and Borah (2020) in an attempt to investigate the impact of Covid-19 on supply chain of manufacturing and retailing firms utilizing twitter data from NASDAQ 100 firms to generate themes regarding the issues faced by firms and the strategies they are adopting using text analytics tool. The study shows that firms are facing challenges in terms of demand-supply mismatch, technology, and development of a resilient supply chain. Apart from profitability, the study also reveals that firms are experiencing difficulties to construct a sustainable supply chain.

\section{Methodology}

\subsection{Data and Sample}

Our sample comprises 150 SMEs across different sectors (Trade, Services, ICT, Education, and Hospitability) in Port Harcourt, River State. Cross-sectional data were collected primarily from the representatives of these SMEs through a structured questionnaire. We recorded a $95 \%$ response rate.

The demographic analysis of the data shows that $75 \%$ of the respondents are male, $80 \%$ are between $25 y$ ears and 50 years, while $60 \%$ completed secondary education. Further, $55 \%$ of the respondents have been in same business for more than 5 years, while $45 \%$ started their business less than five years ago. The analysis also shows that approximately $60 \%$ of the SMEs have previously applied for one form of external financing or the other from banks, while only about $20 \%$ of them achieved success.

\subsection{Variables and Measurement}

We examine financing gap in SMEs in terms of three causal factors: namely, desire to maintain control, information risk, and reputational effects. Based on literature review, we argue that these factors are responsible for the demand-side financing gap in SMEs in Nigeria.

\subsubsection{Risk Aversion}

Risk aversion is the tendency to limit or avoid uncertainty (Hofstede, 1980). Watson, Newby and Mahuka (2009) argues that SME owners with high risk aversion always deliberately avoid seeking external funding or at least, seek limited funding even at the expense of their businesses.

\subsubsection{Desire to Maintain Control}

The desire to maintain control has been identified as among the demand-side factors explaining financing gap in SMEs. According to Cressy (2015), banks' monitoring activities can cause small business owners to experience a loss of control. Watson, Newby and Mahuka (2009) found that failure to apply for external funding can be linked to the desire to maintain control.

\subsubsection{Reputational Effects}

This occurs when a small business owner cannot trust the financial institution and feels discouraged from applying for external funding (Quaye, Abrokwah, Sarbah, \&Osei, 2014). This lack of trust can be due to perceived issues such as stringent information requirement, high bureaucracy, and previous unsuccessful loan attempts.

These variables are measured in Likert scale, with five statements each and options ranging from 1 = strongly agree to 5 = strongly disagree.

\section{Data Analysis}

\subsection{Risk Aversion}

Table 2 shows the means and standard deviations of the responses of small business owners to the five statement items in risk aversion scale. As we can see, almost all the statement items, except RA5, are rated either 'Strongly Agree' or 'Agree' with varying precisions (standard deviations). However, respondents appear indifferent in terms of whether they can go for bank loans despite the unknown factors that make it risky. This shows that risk aversion is considered as a key factor preventing small business owners from applying for bank loans despite the efforts the Federal Government are making to provide more credit for this important sector of the economy. This is consistent with Watson, Newby and Mahuka (2009). 


\begin{tabular}{|c|c|c|c|c|}
\hline $\mathbf{S} / \mathbf{n}$ & Statement Item & $\overline{\boldsymbol{x}}$ & $\boldsymbol{\sigma}$ & Remark \\
\hline RA1 & Bank loans are characterized by so much uncertainty & 4.52 & 0.432 & Strongly Agree \\
\hline RA2 & $\begin{array}{c}\text { I am cautious in applying bank loans even after the } \\
\text { COVID 19 period }\end{array}$ & 3.78 & 0.721 & Agree \\
\hline RA3 & $\begin{array}{c}\text { I would rather stick with informal credit arrangements } \\
\text { than trying out bank loans I am not sure of }\end{array}$ & 3.51 & 0.871 & Agree \\
\hline RV4 & $\begin{array}{c}\text { I am not sure of the hidden charges associated with bank } \\
\text { loans }\end{array}$ & 4.59 & 0.219 & Strongly Agree \\
\hline RA5 & $\begin{array}{c}\text { I can go for bank loans despite the unknown factors that } \\
\text { make it very risky. }\end{array}$ & 3.50 & 0.957 & $\begin{array}{c}\text { Neither Agree } \\
\text { nor Disagree }\end{array}$ \\
\hline
\end{tabular}

Table 2: Risk Aversion Scale

\subsection{Desire to Maintain Control}

Table 3 shows the means and standard deviations of the responses of small business owners to the five statement items in desire to maintain control scale. We can see that all the statement items are rated either 'Strongly Agree' or 'Agree' with varying precisions (standard deviations). This shows that the feeling that bank loans make people lose control or ownership of their businesses is the main factor explaining the financing gap in SMEs. This is consistent with Watson, Newby and Mahuka (2009).

\begin{tabular}{|c|c|c|c|c|}
\hline $\mathbf{S} / \mathbf{n}$ & $\overline{\boldsymbol{x}}$ & $\boldsymbol{\sigma}$ & Remark \\
\hline DMC1 & $\begin{array}{c}\text { I am scared of taking bank loans because of their excessive } \\
\text { motoring activities }\end{array}$ & 4.12 & 0.492 & Agree \\
\hline DMC2 & Bank loans can make one lose control of his business & 3.99 & 0.517 & Agree \\
\hline DMC3 & $\begin{array}{c}\text { I prefer to stay without bank loans so that my business can } \\
\text { remain under my control. }\end{array}$ & 4.51 & 0.277 & Strongly Agree \\
\hline DMC4 & Bank loans are a trap that I am not willing to enter & 4.01 & 0.607 & Agree \\
\hline DMC5 & $\begin{array}{c}\text { People lose fortune to pay up bank loans due to high and } \\
\text { unnecessary charges }\end{array}$ & 4.53 & 0.357 & Strongly Agree \\
\hline
\end{tabular}

Table 3: Desire to Maintain Control

\subsection{Reputational Effects}

Table 4 shows the means and standard deviations of the responses of small business owners to the five statement items in reputational effects scale. We can see that all the statement items are rated either 'Strongly Agree' or 'Agree' with varying precisions (standard deviations). This shows that financing gap in SMEs can be explained by reputational effects. This is consistent with Quaye, Abrokwah, Sarbah and Osei (2014).

\begin{tabular}{|c|c|c|c|c|}
\hline S/n & $\overline{\boldsymbol{x}}$ & $\boldsymbol{\sigma}$ & Remark \\
\hline RE1 & Itatement Item & 3.91 & 0.695 & Agree \\
\hline RE2 & $\begin{array}{c}\text { I have made several unsuccessful attempts in the past to } \\
\text { get bank loans }\end{array}$ & 4.33 & 0.522 & Agree \\
\hline RE3 & $\begin{array}{c}\text { Bank loans involves a lot of bureaucracies and stringent } \\
\text { conditions }\end{array}$ & 4.70 & 0.177 & Strongly Agree \\
\hline RE4 & $\begin{array}{c}\text { I doubt that bank loans are designed for small } \\
\text { businesses }\end{array}$ & 3.93 & 0.604 & Agree \\
\hline RE5 & $\begin{array}{c}\text { I doubt my ability to service bank loans due to } \\
\text { unnecessary charges and interest rates }\end{array}$ & 3.53 & 0.837 & Agree \\
\hline
\end{tabular}

$$
\text { Table 4: Reputational Effects }
$$

\section{Conclusion}

This study is based on a sample of 150 small business owners across different sectors (Trade, Services, ICT, Education, and Hospitality) in Port Harcourt Rivers State. The main conclusions are as follows:

Consistent with previous studies, there is evidence that risk aversion, desire to maintain control and reputational effects are key factors explaining the demand-side financing gap in SMEs in Nigeria. In terms of risk aversion, the results show that perceived hidden charges and high uncertainty associated with bank loans are the most considered factors. On the other hand, the feeling that bank loans take fortune to maintain as well as the fear that taking bank loans can lead to loss of control are the strongest factors explaining the financing gap in SMEs. Finally, the results show that reputational factors such as high bureaucracy associated with bank loans and previous unsuccessful attempts are the key factors explaining the SMEs financing gap.

The implication is that the post COVID 19 era- when all the containment measures would have been relaxed considerably (estimated to be $2^{\text {nd }}$ quarter of 2021) - will witness an economy that is weak and struggling towards recovery. With rising government debt profile, low economic activities and unstable and high domestic prices the economy will be under intense pressure. This might be compounded by a financial system with threatened balance sheet and eager to meet their basic regulatory ratios such as Capital adequacy ratios (CAR), Loan to Deposit Ratios (LDR), Liquidity Ratios 
(LR), and Non-Performing loan ratios (NPL) etc. This means that the Banks will continue to tighten their credit scoring criteria. The Small and Medium Enterprises alreadyhave financing gaps caused by asymmetric information problems, low sales and supply shocks arising from the pandemic. It behoves the SMEs to structure out strategic ways to meet their financing needs.

\section{References}

i. Abraham, F., \&Schmukler, S. L. (2017). Addressing the SME finance problem. World Bank

ii. Research and Policy Briefs, (120333).

iii. Alonso, A. D., Kok, S. K., Bressan, A., O’Shea, M., Sakellarios, N., Koresis, A., ... \&Santoni,

iv. L. J. (2020). COVID-19, aftermath, impacts, and hospitality firms: An international perspective. International journal of hospitality management, 91, 102654.

v. Bartik, A. W., Bertrand, M., Cullen, Z. B., Glaeser, E. L., Luca, M., \& Stanton, C. T. (2020).

vi. How are small businesses adjusting to covid-19? early evidence from a survey (No. w26989). National Bureau of Economic Research.

vii. Central Bank of Nigeria (2020). Economic Report (First Quarter 2020)

viii. Central Bank of Nigeria (2020). CBN policy measures in response to covid -19 outbreak and spillovers. Financial policy and Regulation Department (available at: https//www.cbn.gov.ng/out/2020/fprd

ix. Chemonics International Inc. (2004). 'Assessment of the Micro, Small and Medium Enterprises (MSME) Sector in Nigeria', Promoting Improved Sustainable Microfinance Services Submitted to US Agency for International Development/Nigeria (USAID), 1-213

x. EkpenyongD.BandNyongM.O (1992)'. Small and Medium Scale Business Enterprises in Nigeria: There Characteristics, Problems and Sources of finance'. Economic Research Construction Paper, 16, 1-43

xi. Federal Government of Nigeria (2020). 2021 Budget of Economic Recovery and Resilience. Budget Office of the Federation, Federal ministry of finance, Budget and National Planning AnnualBudget (available @ https//www.budgetoffice.gov.ng. accessed 29/10/2020)

xii. GAIN (2020). Impacts of COVID 19on Small and Medium-Sized Enterprises in the Food System: Results of an Online Survey. Geneva: Global Alliance for Improved Nutrition (GAIN)

xiii. Hadi, S., \&Supardi, S. (2020). Revitalization strategy for small and medium enterprises aftercorona virus disease pandemic (Covid-19) in Yogyakarta. J. Xian Univ. Archit. Technol, 12, 4068-4076.

xiv. Hofstede, G (1980). Motivation, leadership and Organisation: Do American theories apply abroad? Organisational Dynamics (summer), 42-66

xv. International Monetary Fund (2020). Global prospects and policies. World Economic Outlook

xvi. (Chapter 1). October 2020.

xvii. KPMG (2020). The twin shocks (covid-19 pandemic and oil price war) and Implications for the Banking Sector. Advisory brief series

xviii. Le, H., Nguyen, T., Ngo, C., Pham, T., \& Le, T. (2020). Policy related factors affecting the

xix. survival and development of SMEs in the context of Covid 19 pandemic. Management Science Letters, 10(15), 3683-3692.

xx. Lemi, K., Bogale, M., \&Mengesha, W. (2020). The effect of COVID-19 on micro, small and

xxi. medium enterprises' operation in Ethiopia. Journal of Business and economics, 10-17.

xxii. Mouhamadou, L \&Fahd A (2020). African Economies Post Covid-19: Beyond economic Policies. Policy Centre for the New South (available @ https://www.policycentre.ma)

xxiii. Nigeria Bureau of Statistics (2020). Nigerian Gross Domestic Product Report (Q2 2020).

xxiv. Ozili, P. K. (2020). Covid-19 pandemic and economic crisis: The Nigerian experience andstructural causes. Available at SSRN 3567419.

xxv. Ozili, P. K., \&Arun, T. (2020). Spillover of COVID-19: impact on the GlobalEconomy.

xxvi. Available at SSRN 3562570.

xxvii. Quaye, I., Abrokwah, E., Sarbah, A., \&Osei, J.Y (2014). Bridging the SME Financing gap in Ghana: the role of Micro finance Institutions. Open Journal of Business and Management, 2(04), 339.

xxviii. Sharma, A., Adhikary, A., \& Borah, S. B. (2020). Covid-19's impact on supply chain decisions: strategic insights for NASDAQ 100 Firms using Twitter Data. Journal of Business Research.

xxix. Verma, S., \&Gustafsson, A. (2020). Investigating the emerging COVID-19 research trends in the field of business and management: A bibliometric analysis approach. Journal of Business Research, 118, 253-261.

xxx. Watson, J., Newby, R., Mahuka, A (2009). Gender \& SME 'Finance gab'. International Journal of Gender and Entrepreneurship.

xxxi. Wijaya, O. Y. A. (2020). The impact of Covid-19 on micro, small and medium enterprises

xxxii. (MSMEs) in East Java Province, Indonesia and strategies for overcoming: Ad Interim. Journal of Talent Development and Excellence, 12(2s), 3454-3469. 